Alenka Vidrih

Zavod G. G. A. V.

\title{
DRAMSKE DELAVNICE KOT POT OSEBNOSTNEGA RAZVOIA
}

\section{POVZETEK}

Tukaj opisana performativna metoda dramskih delavnic je nastala na podlagi poklicnega odrskega delovanja (igralka, pevka), dela z ljudmi (mentor, trener), stalnega strokovnega izpopolnjevanja ter dolgoletnega raziskovanja in analize uporabe glasu in govorice telesa v izpostavljenem odrskem prostoru in v medosebnem sporazumevanju ter raziskovanja pozitivnih učinkov udeležbe posameznika $v$ ustvarjalnem procesu. Preizkušena je pri delu z ljudmi iz različnih strokovnih okolij in mešanih interesnih skupin.

Pridobljene izkušnje in znanje iz dramskih delavnice uporabniku služijo kot opora pri premagovanju ovir, pri razvijanju strategij preživetja, pri boljšemu razumevanju in sprejemanju sebe in okolja ter pri oblikovanju želenih vzorcev ravnanja. Na tak način udeleženci nase prevzamejo odgovornost za izboljševanje kakovosti življenja. Tako na področju izobraževanja (kjer sta motivacija in interakcija neizbežna elementa kakovostnega prenašanja znanja) kot pri delu z ranljivimi skupinami smo prišli do ugotovitve, da prav način dela udeležencem omogoča preprosto prepoznavanje lastnih in tujih obrazcev obnašanja - videnje sebe in drugih v drugačni luči nevtralizira napetosti $v$ medosebnih in profesionalnih odnosih. Udeleženci izkusijo lastni izrazni in ustvarjalni potencial. Zaupanje v lastne moči in kreativnost povečuje zaupanje v življenje, kar jim ponuja občutek osebne izpolnjenosti. Ugotovitve so zbrane na podlagi zbranih evalvacij, anket, pogovorov, poglobljenih pogovorov, dnevniških zapiskov, dela v skupinah in videoposnetkov ( $z$ dovoljenjem udeležencev).

Ključne besede: umetnostna terapija, dramska delavnica, osebnostni razvoj, ranljive skupine, spreminjanje kakovosti življenja in dela

pisana dramska dejavnost, ki se je razvila v performativni model, je zame nastala kot pesem. Nastane, ker srce tako hoče, in ne po naročilu. Nisem si rekla, nekaj bom izumila, zgolj sledila sem notranjemu vzgibu. Opazovala sem učinke umetniškega ustvarjanja na svojo osebnost in življenje. Temu je naravno in preprosto sledilo še bolj skrbno opazovanje učinkov dramskega ustvarjanja udeležencev mojih delavnic, ki sem jih in jih še zmeraj vodim.
V različnih vsebinskih okvirih izobraževanja in izpopolnjevanja. Prav spoznanje o pozitivnih učinkih igre je bil temeljni navdih za moje delo. Uvidi in spoznanja udeležencev, do katerih so prišli v okviru tako oblikovane dramske dejavnosti, pa so še zmeraj nagrada in navdih za moje vzgojno-izobraževalno delo. Pozorna sem bila torej predvsem na način dela. Želela sem udeležencem omogočiti prostor, kjer ne bodo spregovorili njihovi obrambni mehanizmi 
in odpori, ki ovirajo ustvarjalnost. Želela sem ustvariti prostor, v katerem bi se vsak udeleženec, s podporo vodje in skupine, znal izraziti in uveljaviti na najboljši možen in predvsem sebi lasten način. Ponudila sem jim prostor igre, v katerem udeleženec lahko raziskuje modele izražanja in koliko in kako ti vplivajo na oblikovanje odnosov. Prostor, v katerem si želimo ali s pomočjo katerega postajamo umetniki svojega življenja. Ars Vitae.

Dramska dejavnost, ki jo uporabljamo kot metodo osebnostnega razvoja, je stkana iz gledališke in glasbene prakse. Tkivo, ki veže petje in igro, temelji na doživljanju, osebnem izkustvu. Čeprav vem, da je za uveljavitev dejavnosti treba postaviti nekakšen teoretski okvir, se še vedno zelo borim s tem, da mi teorija ne bi vsega prekrila in bi potem nehala tipati dalje za slutnjami prakse. Igra in petje sta resda praktična podlaga povsem praktične dejavnosti, ne morem pa ljudem, ki nas vprašajo, kaj delamo, odgovoriti: »Pridite, pa boste izkusili.« Treba je pojasniti kaj več.

\section{IGRA KOT ČLOVEKOVA NAJBOLJ OSVOBAJAJOČA PRIMARNA DEIAVNOST}

Ko govorim o prednostih vzgojne dejavnosti, katere temelj je igra, naj se najprej dotaknem tistega vidika igre, ki še ni povezan z dramsko igro oziroma igralskim procesom.

Huizinga (2003: 9) v okviru filozofske razprave z naslovom $O$ izvoru kulture v igri želi dokazati, »da je prava, čista igra temelj in dejavnik kulture«. Razmišljanja o fenomenu igre razgrne takole: »Nekateri verjamejo, da lahko izvor in temelj igre opredelijo kot samorazbremenitev od preobilja življenjske moči. Po mnenju drugih je živo bitje med igro podložno prirojenemu nagonu po posnemanju, zadovoljuje potrebo po sprostitvi, se uri za resno dejavnost, ki jo bo od njega zahtevalo življenje, ali pa mu igra rabi kot vaja v samoobvladovanju«.
»V igri imamo opravka z brezpogojno prvobitno življenjsko kategorijo, ki jo vsakdo nemudoma prepozna, s celovitostjo, če sploh obstaja kaj, kar zasluži to ime. Prizadevati si moremo, da jo opazujemo in vrednotimo v tej celovitosti.«Prav celovitost, o kateri govori Huizinga, je tudi zame ključna vsebina in sredstvo igre. $\mathrm{Z}$ njim lahko razumsko argumentiram smiselnost igre.

Če ponazorim s primerom: Za proces naše prakse velja, da se $\mathrm{z}$ udeleženci »spustimo $\mathrm{v}$ krog igre«, v celostno izražanje in doživljanje. Iz njega potem črpamo sporočila in jih verbalno ovrednotimo. Za nekoga delavnica pomeni stik s samim seboj, na drugi je nekdo prišel do ključnega spoznanja, da je najbolj pomembna oseba v njegovem življenju on sam, in nedavno je neki udeleženec izjavil, da je »vse to, kar delamo (na delavnicah, op. p.) zelo povezano z zaupanjem«. Skupaj smo nato razpletli, da Vsaka igra je pred-
vsem svobodno
delovanje, pa tudi
posnemanje, zau-
panje, sprošćanje. gre pri tem za zaupanje vase in zaupanje $\mathrm{v}$ življenje, da je zaupanje za osebnostni razvoj človeka zelo pomembno, saj mora zaupati tudi drugim ljudem, da se ob njih razvija naprej.

Udeleženci veliko vrednost pripisujejo (po tem, ko ovrednotijo dejavnost) občutku svobode, ki ga ob celostnem izražanju čutijo. Ali kot pravi Huizinga: »Vsa igra je najprej in predvsem svobodno delovanje «.

Kdo si ne želi svobode in spontanosti? Kdo si ne bi v svojem poklicu ali v zasebnem življenju želel občutka svobode in tiste moči, da se sprejme skupaj s svojimi »pomanjkljivostmi«, da si upa biti zmotljiv in nepopoln, zase in tudi v očeh drugih, da je lahko to, kar čuti, da je? Življenje brez neprestanega omejevanja in cenzure, skrivanja sebe. To so teme, želje, cilji in odločitve, ki smo jim priče na delavnicah. Takšna sporočila, vrednotenje dramskih

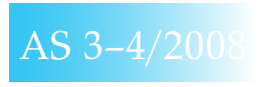


delavnic in misli udeležencev kažejo na večji pomen dramske dejavnosti, kot je tisti, ki se običajno pripisuje drami v prostočasnih dejavnostih in sodelovanju v kulturi.

Dodatno vrednost dramskih delavnic ustvarja mentor, vodja dramskih delavnic, ko aktivnosti povezuje in osmišljuje v odnosu do osebnostnega razvoja posameznika, vpogleda vase, kritičnega obravnavanja osebnih občutkov in v evalvacijskem razgovoru povezuje doživetja s ciljem, ki naj bi ga po več dramskih delavnicah tudi dosegli. Celostno in spontano izražanje udeležencev in delovanje sta osrednji kvaliteti vsebin dramskih delavnic.

\section{IZHODIŠČNA PRAKSA MODELA DRAMSKIH DELAVNIC TER PRE- MIK NA PODROČJE APLIKATIV- NIH GLEDALIŠKIH DEJAVNOSTI IN DRAMSKE TERAPIJE}

Performativni model je v osnovi nastal predvsem iz procesa dela profesionalnega igralca. Ta ima teoretsko podlago gledališke umetnosti, pridobiti pa si mora tudi znanje znanstvene discipline o osebnostnem razvoju, vzgoji in izobraževanju odraslih - andragogike. Pri te-

Dramska terapija uporablja metode in tehnike igre za doseganje psihosocialnega zdravja posameznika in družbe. oriji dramske igre (v nasprotju $\mathrm{z}$ gledališko teorijo) gre bolj za zapise posamične igralske prakse. Največje in največkrat omenjeno ime v zvezi s tem je zagotovo Stanislavski. Še danes pravzaprav ni jasno (niti ni zaznati posebne družbene potrebe po tem), koliko gre pri igralcu za obrtniško znanje in nadarjenost in koliko za umetnost. Stvari imajo v gledališki praksi največjo težo, kadar so povezane z dobrim rezultatom, navdušenim občinstvom in pozitivnim mnenjem gledališčnega kritika o konkretni gledališki predstavi. To pa je prepričljiva dramska akcija igralca, ki vpliva na doživljanje drugih, občinstva. Pri dramskih delavnicah so doživetja osebe, ki igra, ključnega pomena zanjo osebno. Odkrijejo naj ji nova spoznanja o sebi, odnosih z ljudmi, potisnjenih čustvih in uvid v vrsto osebnih doživljanj.

Prava osnova za vrednotenje oziroma pomen igre za igralca samega in s tem novih teoretskih parametrov se je tako prijela šele v kontekstu dramske in igralne terapije. Šele ko si je igra pridobila značaj uporabne umetnosti in se tako znašla $v$ povezavah $\mathrm{z}$ znanostmi o človeku. In seveda sem se najprej kot študentka in kasneje predavateljica tudi sama znašla na podiplomskem študiju Pomoči z umetnostjo na Pedagoški fakulteti v Ljubljani.

\section{UMETNOSTNA TERAPIJA IN DRAMSKE DELAVNICE}

Na straneh Združenja umetnostnih terapevtov Slovenije smo zapisali, da je dramska terapija dinamična oblika dejavnosti, dramski ustvarjalni proces, metode, tehnike, sredstva in rezultate igre pa uporablja kot medij/orodje za dosego psihosocialnega zdravja posameznika in družbe.

Temeljne značilnosti tega pristopa so tako aktivna udeležba posameznika $\mathrm{v}$ dramskem ustvarjalnem procesu kot njegova osebna izkušnja pri tem (izkustveno učenje) ter tema igre, ki je gibalo dejavnosti. Je obenem način in vsebina dejavnosti. Kot didaktična metoda igranja vlog se $\mathrm{v}$ andragoški praksi izvaja in uporablja na mnogih področjih človekovega osebnega in poklicnega usposabljanja kot samostojna ali kot dopolnjujoča dejavnost.

Tako na področju preventivnih kot na področju kurativnih zdravstvenih dejavnosti. V smislu preventive posameznika podpira pri vzdrževanju psihosocialnega zdravja, osebnega ravnotežja in pri njegovem poklicnem ali osebnem celostnem razvoju. Zato dramske delavnice postajajo zanimive v organizacijah državnega, zasebnega in civilnega značaja; pri vzgoji in 
izobraževanju, usposabljanju, svetovanju, izpopolnjevanju in $\mathrm{v}$ prostočasnih dejavnostih ter dejavnostih medosebne pomoči in samopomoči.

\section{USPOSABLJANJE MENTORJEV, UMETNOSTNIH TERAPEVTOV}

V Sloveniji je organiziran podiplomski študij, na katerem študent pridobi naziv »specialista pomoči z umetnostjo«. Študij poleg ožje usmerjenega modula vsebuje tudi skupnega. Koncept torej ne izpostavlja posameznega umetnostnega področja, čeprav se študent ožje specializira na enega izmed njih, odvisno od tega, v kateri umetnostni panogi je usposobljen (slikanje, glasba, drama). To mu kasneje pri delu daje širino in tudi boljše konkretne možnosti, da se približa z uporabniku bližjim medijem.

Pogled na igro kot terapevtsko dejavnost in s tem povezana znanja so me dokončno utrdila v prepričanju, da sem na pravi poti. Pionirska dejavnost, perforamativna metoda dramskih delavnic, pri kateri sem skoraj trmasto vztrajala in jo dosledno razvijala, je našla svojo družino: aplikativne gledališke in dramske dejavnosti. Med njimi naj naštejem nekatere bolj poznane in ožje usmerjene, psihodramo, tetroterapijo, Playback Theatre, Theatre in School. $\mathrm{V}$ zadnjih letih se je uveljavilo tudi socialno gledališče kot pojem aplikativne gledališke dejavnosti. Njegov terapevtski učinek je iskati bolj znotraj njegove izrazitejše funkcije re-socializacije udeleženca. Sama ga razumem kot odziv na nove potrebe družbe. Obenem pa se ponuja kot možnost, da se gledališčniki izprašamo v zvezi s primarno funkcijo in $\mathrm{z}$ njo povezanimi oblikami gledališča ter preverimo vlogo, smiselnost in pomen gledališča $\mathrm{v}$ današnjem času. O umetnosti v okviru teh dejavnosti govorimo kot o mediju, s pomočjo katerega se izrazimo. Pravimo tudi, da dramska umetnost služi kot »orodje«.

\section{IZHODIŠČNE VSEBINE MODE- LA AV-DRAMSKIH DELAVNIC OSTAJAJO NJEGOV TEMELJNI PRISTOP}

Izpostavila bom prednosti, ki jih je mogoče razvijati, zaradi vsebine in metode dela znotraj igralskega procesa, kot sem jih razumela, sistematizirala in doživljala sama.

Za udeležence delavnic sem skušala ohraniti tiste tehnike, vaje in postopke, ki jih v življenjskem procesu lahko zavestno razvijamo in $\mathrm{z}$ njimi krepimo opisane psihofizične lastnosti in spretnosti. To sem nato povezala $\mathrm{z}$ drugimi pridobljenimi veščinami ter znanji s področja dela z ljudmi in veščinami vzhodne kulture. Želela sem z ljudmi razdeliti pozitivno dramsko in življenjsko izkušnjo na način, za katerega verjamem, da kljub svoji mehkobi in lahkotnosti (ali prav zaradi nje) vsebuje preobrazbeno moč. Performativni model dramske delavnice je za današnjo obliko potreboval celo desetletje razvoja.

Igralec, ki ga imam tokrat pred očmi, v sicer kratko odmerjenem »odrskem času in prostoru«, ki ga ima na voljo za svoje delo, je podoben prizadevnemu učitelju, ki mu sploh ni vseeno, ali mu bodo učenci verjeli ali ne, in ima svoje delo zelo rad. Pred učno dejavnostjo mentor potrebuje temeljito pripravo. Na začetku mu ta vzame dobršen del časa, z leti pa se čas predpriprave skrajša. Igralec je, preden postane odrski akter, tudi temeljit opazovalec. Opazuje in dela male raziskave sodelujočih oseb, prav tako kot znanstvenik. V vadbenem odrskem času jih potem preizkuša. Kot pri vseh intelektualnih poklicih bogati svoje znanje z literaturo. Sem spada predvsem raziskovanje osebnosti in razmerij, $\mathrm{v}$ katera so povezani določen igralski lik in principi osebnostnega razvoja. Pomembno je tudi razumevanje časa in prostora, v katerem se odvija bodoče odrsko življenje njegovega lika. Poleg intelektualnega pa je pomembno tudi čutno, izkustveno in čustveno razumevanje. Pri tem mu pomagata vadba ter vzdrževanje sposobnosti in 
Igralec mora lik ne le razumeti in izraziti skozi besede, temveč izraziti skozi telo, ga celostno dojeti in se vanj vživeti. Pri tem in pri celostnem razumevanju igralskega lika mu je v največjo pomoč sposobnost vživljanja oziroma čustvena empatija. Prav z njeno pomočjo svojo igralsko vlogo ne razume in dojame le razumsko, temveč tudi na neki drugi, neracionalni, doživljajski, čustveni ravni. Da bi igralec prepričljivo izražal svoj čustva, občutke in besede, da bi bile njegove geste $\mathrm{v}$ skladu z jezikom, ki ga kot lik uporablja, z besedami, ki jih na odru izgovarja, mora za ta »odrski čas « svoji vlogi podrediti tudi svoj miselni svet. Zavzeti mora stališča igralskega lika, prepričanja. Poiskati mora prave misli. Kajti, kot pravimo, doživljanje se vidi.

spretnosti lastnega »inštrumenta«. Pomembno je torej ne le širjenje znanja, temveč tudi urjenje duha in telesa.

Od igralca se pričakuje, da se ne le giblje, temveč celo diha kot lik in celostno izraža sebe. Življenja liku ne vdihnejo besede, temveč njegova celovita osebnost, ki se manifestira skozi njegovo pojavnost in skozi njegovo izražanje občutkov, počutja, besed. Zato je treba vstopiti v njegov čustveni in čutno zaznavni svet. Da bi optimalno oblikoval vlogo, naj bi bil njegov čutno zaznavni instrument (telo, glas) prožen. Poleg njegove bogate domišljije in palete čustvenih izrazov naj bi bila njegova izrazna sredstva razgibana in pestra, krasila naj bi ga širina osebnosti in karizma ter originalnost.

Naj lastna razmišljanja o pozitivnih učinkih igralskega procesa in veščin podkrepim še z mislimi drugih avtorjev. V svojem delu Igralska umetnost $\mathrm{v}$ zvezi z razvijanjem igralčeve izraznosti in originalnosti (kot sestavnega dela ustvarjalnega procesa) Čehov M. zapiše: »Ko oblikujete dramski lik in ga hkrati opazujete od strani, je vaša ustvarjalnost pogosto sama presenečena nad tem, kar je nastalo. Vse, kar delate na odru, je tudi za vas novo in nepričakovano, saj vaš 'višji jaz' vedno improvizira. Noče in ne more uporabljati starih gledaliških prijemov in klišejev « (Čehov, 1999: 190). Ravnjak poudarja pomen fantazije in predstavljivosti in pravi: »Sposobnost imaginiranja je osnova igre in igranja, hkrati pa je tudi osnova sleherne ustvarjalnosti« (Ravnjak, 2005:107). Kot človek z igralsko prakso verjamem, da gre pri poklicu igralca za »ohranjanje otroka $\mathrm{v}$ sebi« po profesionalni dolžnosti. Povezano je $\mathrm{z}$ večno radovednostjo in principom analogije. Po Ravnjaku gre pri slednjem zato, da »smo sprejeli trik igre «. Če ustvarjalna psihologija raven ustvarjalnosti povezuje $\mathrm{z}$ otroško dušo, potem je dejavnost, ki neguje »otroka v sebi«, zagotovo dobrodošla.

\section{VZGOJNI CILJI AV-MODELA DRAMSKIH DELAVNIC}

$\mathrm{V}$ nasprotju $\mathrm{z}$ večino metod in oblik vzgojnoizobraževalnega dela, ki sicer vključujejo igranje vlog, model AV-dramskih delavnic izhaja prav iz igralčevega profesionalnega procesa dela in razvoja vloge ter udeležence opremi s tehnikami, ki povečujejo strategije preživetja v izpostavljenem odrskem prostoru. Tako kot igralec tudi udeleženec AV-dramske delavnice zavestno krepi odprtost, spontanost in senzibilnost in obenem notranjo oporo in pogum, ki je potreben za izražanje in uveljavljanje doživetij. Osrednji vzgojni cilj naših AV-dramskih delavnic je raziskovanje razsežnosti čutno zaznavne strukture posameznika; razvijanje njegove čustvene in telesne inteligence; s tem povezano razvijanje psihofizičnih sposobnosti in spretnosti, od katerih se je posameznik, s predolgim zadrževanjem predvsem na področju uma, oddaljil.

$\mathrm{S}$ pomočjo performativne izkušnje v odrskem prostoru razkrivamo in pod drobnogledom opazujemo ter razčlenjujemo različne telesne manifestacije osebnostne strukture. $\mathrm{Z}$ različnimi tehnikami raziskujemo ne le vzorce, temveč 
korenine svojega izražanja, odzivanja, razmišljanja, čutenja in ravnanja z drugimi. Raziskujemo obrambne mehanizme osebe in strategije preživetja, vzorce socialnega vedenja, ki se odražajo v naši govorici telesa, s čimer se sooča dramski igralec, ki ga imam v mislih, pri svojem profesionalnem procesu dela.

\section{OPIS PROCESA AV-MODELA DRAMSKIH DELAVNIC IN NJENE POSEBNOSTI}

Osrednja značilnost, gibalo performativne metode AV-modela dramske delavnice je performativna izkušnja posameznika. Zato je delo razdeljeno $v$ tri faze:

Prva faza: ozaveščanje trojčka, je temelj, ki ga udeleženec osvoji $\mathrm{v}$ začetku učnega procesa, da bi lahko kasneje neovirano nadaljeval učenje $v$ drugi fazi. Ta faza se $v$ nekaterih zapisih o postopku imenuje tudi instrumentalizacija telesa. Gre za vzpostavljanje čutne zaznave in umirjanje miselnih procesov.

Druga faza: pridobivanje tehnik za celostno izražanje. Govorica telesa postaja bolj usklajena že z samim ozaveščanjem. S tehničnimi vajami, urjenjem človekovega instrumenta (telo, misel, dih) ter pripomočki (notranji koordinatni sistem, nevtralna drža, vokalne govorne in jezikovne vaje) pa posameznik vzpostavlja tako imenovano notranjo oporo, ki temeljno prispeva $\mathrm{k}$ razumevanju in izvedbi naslednje, tretje faze.

Tretja faza predstavlja ustvarjalni del. V varnem okolju paralelnega časa in prostora (odrskega prostora) posameznik prepoznava, preizkuša in ustvarja nove modele:

- telesnega obnašanja in drže;

- miselnih modelov, razmišljanja;

- dihanja;

- govora;

- ravnanja (delovanja, sporočanja).

$\mathrm{Z}$ uporabo pridobljenih izkušenj in tehnik posameznik vzpostavi tako imenovano avtentično držo, s katero vstopa in izstopa ter prožno prehaja med vlogami.

Dosledna uporaba metode dramskih delavnic AV pri posamezniku omogoča uvid v modele sporazumevanja ter uvedbo sprememb $\mathrm{v}$ zgoraj naštetih modelih njegovega izražanja, ravnanja, sporazumevanja. Kažejo se v odnosu in ravnanju do sebe in drugih, $v$ poklicnem in osebnem življenju (življenjske, poklicne in partnerske vloge). Spremembe modelov iz paralelnega, odrskega prostora posa-
Glavna metoda $A V$-modela je performativna izkušnja posameznika. meznik postopoma, lahkotno, spontano ter zato komaj opazno, ob ustrezni podpori mentorja, prenaša v različna življenjska okolja.

S pomočjo AV-metode dramskih delavnic posameznik odkriva notranje ustvarjalne potenciale, ki jih nato uporabi za krepitev svojih prednostnih lastnosti in oblikovanje novih modelov izražanja in sporazumevanja. Govorica telesa, izražanje in ravnanje posameznika postane avtentično, ker vse bolj odkriva sebe. Sporočilo, ki ga posameznik želi usmeriti na drugega človeka, postane izrazno usklajeno z vsebino sporočila. Misel, dih in telo (govor, glas, drža) se medsebojno ujemajo, so usklajeni, nesporno podprti s tem, kar oseba, ki sporoča, čuti. Ko ne prihaja do tako imenovanih lomov med neverbalnim in verbalnim izražanjem posameznika, govorimo o celostnem izražanju. Zanj je značilno dobro sodelovanje desne in leve možganske polovice. Racionalnost, urejenost in metapozicija na eni ter intuicija, senzibilnost, empatija, čutna in čustvena odzivnost ter spontanost na drugi strani. Pri tem posameznik uporabi izrazna sredstva, ki so mu na voljo (velja tudi za tiste, ki imajo težje gibalne ali druge ovire). 
Mentor vodi posameznika s pomočjo sinhronizacije skozi proces dramskoterapevtske dejavnosti. Trdna struktura AV-metode dramskih delavnic omogoča postopno usklajevanje med zunanjim izrazom in notranjim počutjem (ter miselno naravnanostjo posameznika). Skozi dramski proces predelamo vsebine, ki so pomembne za naše življenje in izražanje, sporazumevanje z drugimi. Posvečamo se oviram v izražanju in sporazumevanju, ki za nas predstavljajo nekakšno seme, izziv za samoraziskovanje in osebno rast.

Dramski igralec oziroma udeleženec v AVprocesu dramske delavnice svojo vlogo »živi«. Takrat pravimo, da v svoji vlogi »žari« in je prepričljiv. S pomočjo pridobljenih tehnik nato nevtraliziramo ovire, ki smo jih pri izražanju prepoznali. Struktura modela je oblikovana tako, da je akcijsko učenje po potrebi, pri večjih odstopanjih osebnosti tudi terapevtski proces. Znotraj dejavnosti, ki so povezane s programskimi cilji, ki jih želimo doseči, se učinki v skupinah prepletajo. Tako obenem govorimo o osebni rasti, obravnavi učnih vsebin, pa o terapevtskih učinkih in o pridobivanju spretnosti v izražanju in sporazumevanju.

V okviru vseh programov, ki jih v Zavodu izvajamo, se udeleženci seznanijo s tehnikami, ki jih utrjujejo skozi proces. Z njihovo pomo-

Rezultat delavnic je posameznikovo boljše obvladovanje stresa, pridobljena spretnost $v$ sporazumevanju in osebna rast. čjo gredo skozi trening izpostavljenosti, v katerem ovire prepoznavajo in ki je bistvena vsebina AV-metode dramskih delavnic. Obravnavamo in odpravljamo jih $\mathrm{v}$ odrskem prostoru in s pomočjo dramskih situacij. Tehnike in izkušnje, pridobljene znotraj dramsko-terapevtskega procesa, so stranki $\mathrm{v}$ oporo tako na delovnem mestu kot v zasebnem življenju.

Univerzalni cilj srečanj sta strokovna in skupinska podpora ter tehnična pomoč pri tem, da bi udeleženec obvladal življenjske vloge in strategije preživetja v izpostavljenem življenjskem prostoru ter tako zvišal kakovost svojega

Če je cilj igralca, da se v celoti zlije z igralsko vlogo in zavzame avtentično držo, je cilj udeleženca AV-dramske delavnice, da se zlije s svojo življenjsko vlogo in postane avtentičen.

življenja, razvil svoje prednosti ter se prepoznal v najboljši luči. Prek zaupanja vase pridobi tudi večje zaupanje v življenje.

\section{KAJ LAHKO ŠTUDENT PRIDOBI V DRAMSKIH DELAVNICAH?}

Raziskovanje v okviru procesa je lahko dolgotrajno ali pa se zgodi bliskovito. Vloge, ki jih obravnavamo v dramskem prostoru AV-delavnic, so glede na vsebinski okvir skupine lahko družinske vloge, druge socialne vloge (v odnosu, jaz - prijatelji, družba, okolje, šola) ali poklicne vloge.

Naj povedano ponazorim s konkretno primerjavo. Igralec v gledališču bo vlogo javnega uslužbenca in besedne zveze preigraval ter preverjal $\mathrm{v}$ odrskem prostoru. $\mathrm{V}$ odnosu $\mathrm{z}$ drugimi gledališkimi ustvarjalci (feedback) bo izbiral med mnogimi niansami, na primer, vse od pritlehnega, robustnega do prefinjenega in ustrežljivega uradnika. Na koncu bo izbral takšnega, ki bo najbolj ustrezal njegovi lastni predstavi, in si pri tem pomagal s predstavo drugih ustvarjalcev o njem.

Udeleženec AV-procesa dramske delavnice, ki je po poklicu dejansko javni uslužbenec, bo v okviru delavnic AV preigraval (s pomočjo prej pridobljenih orodij) vse možne izraze svoje poklicne vloge. Glede na preizkuse in lastna spoznanja ter s pomočjo skupine in vodje bo v odrskem prostoru spremenil lasten profesionalni izraz. Če še bolj konkretiziram, javni uslužbenec je z udeležbo v AV-procesu dramske delavnice prepoznal svoje omejitve na podlagi lastnega uvida in ne zaradi prigovarjanja kolegov in strank. 
$\mathrm{Z}$ uporabo igralskih tehnik $\mathrm{v}$ dramskih delavnicah udeleženci prepoznavajo svoje prednosti in odpravljajo tiste ovire, ki onemogočajo, da bi v svoji družinski, socialni in profesionalni vlogi polno zaživeli tudi $\mathrm{v}$ najboljši luči. Poleg tega udeležencu dramska delavnica ponuja okolje, v katerem bo bolj varno raziskoval in preizkušal, kar v realnih življenjskih okoljih ne bi bilo varno.

Prav takšna strukturiranost srečanj in pridobljena orodja so bistvena pridobitev za udeleženca. Šele ta namreč dopuščajo kasnejšo spontanost in občutek svobode. To dvoje pa omogoča, da v igro voljno in $\mathrm{z}$ radostjo privolijo, se v igro potopijo in se v njej za neki določen čas ustvarjalno izgubijo.

Kot prednost dela v okviru delavnice velja omeniti tudi, da prav struktura srečanj omogoča dovolj medsebojnega spoštovanja. Prav zaradi posrednosti sporočanja, prek medija gledališča, omogoča nedirektivno prenašanje. Stopnjo interaktivnosti povečujeta še skupinski raziskovani proces in skupno strukturiranje vsebine. Pomembno pa je omeniti, da udeleženec podporo obenem pridobiva in ponuja.

Dramska terapija v obliki tukaj opisanih delavnic dejavnosti pa s tem ne posega $\mathrm{v}$ prostor vrhunske umetniške ustvarjalnosti, niti ljubiteljske dejavnosti (mimogrede, pri obeh omenjenih gre za tako imenovani nezavedni terapevtski učinek), temveč po svojih močeh le smiselno odgovarja na potrebe človeka v tem času in prostoru in tako načrtno posega $\mathrm{v}$ osebnostni razvoj posameznih ljudi.

S stališča, da je življenje lahko lepa igra, udeleženec ob koncu procesa pridobi naziv: AVakter, kar simbolizira korak, s katerim je stranka prevzela aktivno vlogo v svojem življenju oziroma je postala umetnica življenja. Posebno pozornost pa mentorji namenjamo varnosti in profesionalnemu razvoju trenerja, zato se srečujemo na tedenskih delovnih srečanjih, v okviru intervizije, supervizije in pri vodenju skupin praviloma delujemo $\mathrm{v}$ paru.

\section{OSEBNOSTNA RAST IN POMOČ RANLJIVIM SKUPINAM}

AV-delavnica vzame »življenje pod drobnogled « tako, da izkorišča »odrski prostor«, predvsem za raziskovanje in izražanje neizrečenosti in neizživetosti ter v prid urejanja življenjske zgodbe. V takšni obliki je primerna tako za skupine starejših odraslih kot skupine mladostnikov, skupine s specifičnimi težavami in ovirami ter tiste ljudi, ki so porinjeni na rob socialnega življenja, skratka za delo z ranljivimi skupinami. Predstavlja neprisiljen in lahkoten okvir, ki ne stigmatizira posameznikov na primer kot »vedenjce«, »upokojence« ... V dramskem prostoru želimo urediti življenjske/ delovne zgodbe $\mathrm{z}$ obravnavo življenjskih nalog. Obravnavamo čim več vidikov socialnih vlog iz okolja, v katerem živijo (družina, družba, šola). Največkrat prijetno in včasih humorno se ukvarjamo predvsem s prepoznavanjem ovir in potem skupaj iščemo možnosti, kako jih premostiti.

Takšna dejavnost povečuje razumevanje lastnega življenjskega položaja in razteza obstoječe okvire in merila socialnih/življenjskih vlog. Pri tem pa ponuja okvir za njihovo preobrazbo.

V prostoru igre, na primer, z udeleženci obravnavamo množico impulzov, vzgibov, reakcij, ki so se jih v življenju vzdržali. S pomočjo izmišljenih okoliščin in $\mathrm{z}$ vizualiziranjem, s spodbujanjem domišljije črpajo iz množice neizrečenih misli, zamolčanih besed, zadržanih dejanj in zadržanih dihov. Naj spet poudarim: v prostoru igre jih prek izmišljenih okoliščin izživijo, izrečejo in predihajo. Kolikor pač dopuščajo psihofizične zmogljivosti posameznega udeleženca. Če ne drugače, to naredimo skozi metafore. Skozi misli, dejanja in dih odrskega lika. Ne gre za identične osebe in okoliščine, 
vendar pa so z njimi povezane prek občutkov, čustvenega spomina in čutne zaznave, ki so tukaj in zdaj in lahko veljajo za nazaj.

Ponazoritev s primerom: Udeleženka je skozi AV-proces dramske delavnice prepoznala lastno neodločnost. Ozavestila je razliko med izražanjem želje in postavljanjem svojih zahtev. To pa kot temeljno oviro za neuspešnost komunikacije s svojim otrokom in sodelavci. Sledila je obravnava prepričanj. Ozavestila je tudi osebnostno negotovost, ki se je manifestirala skozi nejasnost v komunikaciji. S pomočjo procesa ji je v odrskem prostoru uspelo realizirati in okusiti svojo odločno naravo in

Performativno metodo je mogoče uporabljati pri delu z ljudmi, kot so vodenje in upravljanje, stiki z javnostmi, posredovanje znanja ipd. izraz. Posledično je razvila boljšo komunikacijo in omenjen odnos.

Sem sodi še najbolj nenavadna skupina, ki želi razviti sposobnosti samopomoči in sprostitve s pomočjo igre, ki jo želi vplesti v življenje. Gre za skupino udejanjanja profesionalnih vlog.

Profesionalne vloge v delovnih okoljih povzročajo pri nekaterih veliko nezadovoljstva in želje po spremembi: v smislu preobrazbe komunikacijskih obrazcev razvija in krepi: izrazna, komunikacijska sredstva udeleženca (telo, glas, govorni aparat), razčlenjuje in razpostavlja, analizira in prerazporeja v nove kombinacije stare ali razvija nove komunikacijske vzorce. Cilj tega je ujemanje komunikacijskih modelov s profesionalnimi zahtevami in nalogami. Koraki procesa so v poklicnih vlogah podobni kot v družinskih vlogah: raziskujemo - ozaveščamo - presegamo - spreminjamo modele osebnega izražanja, sporočanja, sporazumevanja, predajanja znanja na delovnem mestu. Skratka, delavnica omogoča podporo za tista delovna okolja, kjer profesionalizacija odnosov ni dobro stekla in se odnosi kvarijo.

Ponazoritev s primerom: oseba, ki je bila v delovnem okolju prepoznana za nestrpno in celo napadalno, se je znotraj procesa izkazala za človeka z izjemnim intelektualnim potencialom. V okviru delovnih nalog ni mogla izkoristiti svojega potenciala, kar je povečevalo njeno nezadovoljstvo. Skozi vaje znotraj procesa je prišla oseba sama do uvida $v$ zvezi $\mathrm{z}$ nenehnim prenašanjem nezadovoljstva na druge. To ji je omogočilo, da neustrezni model obnašanja nadomesti z ustreznim, obenem pa je naredila načrt za poklicno spremembo. Ena izmed udeleženk je bila tudi profesorica pred operacijo glasilk, ki je v skupini prišla do nekaj zanjo pomembnih odgovorov in vaj ter se $\mathrm{z}$ vztrajnostjo rešila pred operacijo vozličkov. Delavnice pa se udeležujejo tudi skupine ljudi, ki delajo z ljudmi, bodisi tako, da prenašajo znanje ali imajo vodstvene funkcije v kadrovskem in gospodarskem menedžmentu ter $\mathrm{v}$ državni upravi, kot tudi pri medijskih in akterjih v službah za stike $\mathrm{z}$ javnostmi.

$\mathrm{V}$ vseh opisanih primerih gre za osveščanje in odpravljanje ovir pri izražanju in sporazumevanju. Obravnavi družinskih in profesionalni vlog se prepletata. V skupinah, ki so namenjene prenovi komunikacije, obenem dosežemo vzgojni in/ali celo terapevtski cilj.

\section{KJE UPORABLJAMO DRAMSKE DELAVNICE?}

Metodo je mogoče uporabiti kot aplikativno metodo pri delu z ljudmi, kot so vodenje in upravljanje ter posredovanje znanja (obravnava učnih vsebin). Samostojno uporaben model velja v ranljivih skupinah, kjer gre za obravnavo življenjskih, socialnih vlog ter pri uravnavanju in oblikovanju ustvarjalnega vzdušja, pri profesionalizaciji odnosov. Značilna področja uporabe so torej javno šolstvo in izobraževanje odraslih, socialne službe in druga področja, kjer se ukvarjajo z ljudmi, zdravstvo ter javne, državne in zasebne organizacijske strukture. AV-model dramske delavnice kot samostojen proces in oblika vzgojne dejavnosti je name- 
njen vsem ranljivim skupinam (sem sodijo tudi tisti z manjšimi in večjimi prepoznanimi ovirami) in dramskim skupinam, ki želijo znotraj prostočasne dejavnosti izluščiti preobrazbeno moč.

Uporabniki: Zavod za slepo in slabovidno mladino, Dom za ostarele, Zavod Soča, centri za socialno delo, andragoške ustanove, programi za zdravljenje alkoholikov, mladinski programi v okviru MOL, šole, projekti Grundtvig in kadrovske službe v podjetjih.

Dramske delavnice so pomemben del prizadevanj tudi za oblikovanje usklajenih timov (team tuning). Skupini sodelavcev omogoča, da ustvarijo kakovostne odnose, se razvijejo v usklajen tim in se tako osredotočijo na konstruktivno delo, če posamezni člani ozavestijo osebne ovire za sodelovanje in se delno spremenijo. Pogosto so uporabniki takih programov: delovne organizacije, projektni timi, ministrstvo za šolstvo, ministrstvo za obrambo, izobraževanje odraslih in podobno.

Dramske delavnice so koristne pri tako imenovanem ustvarjalnem nevtraliziranju stresa. Posameznikom in skupini pomagajo, da znajo sami prepoznati in odpraviti okoliščine, ki ustvarjajo napetosti na delovnem mestu ali v družini. Poudarek je na tem, da sami prevzamejo iniciativo in se zavejo lastnega prispevka in vpliva ter tako po svojih močeh poskrbijo za pozitivno in spodbujajoče okolje, v katerem delujejo. Uporabniki so predvsem delovne organizacije, v katerih so zaposleni pod velikim stresom in kjer zaposlenim grozi izgorelost.

Igranje vlog in dramske delavnice so idealne poti za usposabljanje brezposelnih in nove iskalce služb, ker je zelo pomembno, kako se znajo predstaviti. S pomočjo mentorja trenirajo retorične veščine, spretnosti in vrline, ki so pomembne za kakovostno osebno predstavitev in javni nastop. Omenjenih dveh programov ne izvajamo v »izoliranem času in prostoru «, temveč v aktualnem delovnem okolju oziroma predvidoma med delovnim časom. Tudi izkušnje iz dramsko-terapevtskega procesa preizkušajo in vnašajo neposredno $\mathrm{v}$ delovno okolje. Srečanja običajno (z izjemo bolj intenzivnih programov AV-krmiljenja) potekajo enkrat na teden po uro in pol. Proces obsega obdobje od polovice do enega leta. Pri individualnem in timskem učnem krmiljenju se ustvarja dolgotrajnejši odnos z naročnikom, sodelovanje med mentorjem in vodeno osebo je postopno in dolgotrajno ter zelo zgoščeno. Zabavnejši del našega programa poveže dramske delavnice, učenje z bolj zabavnim delom Delovno ali učno okolje namenoma preusmerimo v družabno okolje. S tem dosežemo višjo stopnjo sproščenost zlasti pri osebah, pri katerih pričakujemo neke spremembe.

\section{KAJ JE VLOGA MENTORIA ALI TRENERJA?}

Posameznika skozi proces vodi mentor ali trener, ki ga za tukaj opisano metodo dramskih delavnic posebej usposobi avtor te metode. Trener dosledno in odgovorno upošteva predvidene stopnje ter tako omogoča varno in ustvarjalno okolje za raziskovanje in spreminjanje modelov izražanja, delovanja, sporočanja, sporazumevanja. Pri tem ponudi posamezniku vso potrebno in ustrezno podporo. Tako v odrskem prostoru kot kasneje pri prenašanju novih, želenih modelov $\mathrm{v}$ realna življenjska okolja posameznika.

Trenerji dramskih delavnic smo osredotočeni na preventivno dejavnost, ki pa $\mathrm{v}$ mnogih primerih bistveno spreminja pogled posameznika na življenje. Še več, od trenerja se pričakuje, da bo udeleženca podpiral tudi z lastnim zgledom, z lastno ustvarjalnostjo, razgibal, ga navdihoval ter spodbujal k ustvarjalnemu izražanju in ga podprl, da pride do lastnih uvidov in spoznanj $\mathrm{v}$ 
zvezi s svojo obliko sporočanja ter delovanjem in vplivanjem na druge.

\section{TRENER UDELEŽENCE SPODBU- JA, DA IZKUŠNJE IZ DRAMSKIH DELAVNIC VNAŠA NA VSA PO- DROČIA ŽIVLJENIA}

$\mathrm{V}$ umetnostno-terapevtskem procesu smo do svojih udeležencev strpni, prizanesljivi in ustvarjalni, spodbujamo kreativen dialog z jasno usmeritvijo v pozitivno, konstruktivno naravnanost, v konsenz. Dialog zunaj procesa ne more biti povsem drugačen. Mentor ali trener, umetnostni terapevt z jasno izraženimi stališči o pomenu strpnosti in nenasilja je najboljši promotor svoje dejavnost. S svojim delom prispeva h kulturi dialoga in kontaktni kulturi. Ne s prepričevanjem in opisovanjem, ampak tako, da omogoča, organizira in navaja na neposredna doživetja, uvid in samokritičnost udeleženca. Mentor ali trener, umetnostni terapevt - vzgojitelj širi zavedanje o pomenu razvijanja osebnostnih kvalitet, vrednot in ustvarjalnosti. Zaveda se, da prav te povečujejo kakovost bivanja, povečajo zaposljivost osebe in ji zagotavljajo kompetentnost za delovanje v poklicu in družini.

Več o Zavodu G. G. A.V.: www.alenkavidrihzavod.si

\section{LITERATURA:}

Strehovec, J. (ured., 2003). Teorije igre pri Johanu Huizingi, Rogerju Cailloisu in Eugenu Finku. Ljubljana: Študentska založba.

Ravnjak, V. (2005). Spoznavanje višjega jaza. Maribor: Gnostica.

Schwarz A. Ronald, P. (2005). Moč podzavesti, Nevrolingvistično programiranje. Ljubljana. Mladinska knjiga.

Vidrih, A. (2007). »Na stičišču umetnosti, izobraževanja in terapije«. V: Human Resource Management. Ljubljana. 